\title{
Non-canonical Estrogen Signaling in Endocrine Resistance
}

\author{
Prathibha Ranganathan*, Namratha Nadig and Sughosha Nambiar \\ Centre for Human Genetics, Bengaluru, India
}

Breast cancer is one of the leading causes of cancer related deaths in women worldwide. The disease is extremely heterogenous. A large percentage of the breast cancers are dependent on estrogen signaling and hence respond to endocrine therapies which essentially block the estrogen signaling. However, many of these tumors emerge as endocrine resistant tumors. Many mechanisms have been proposed to explain the emergence of endocrine resistance, which include mutations in the estrogen receptors, cross-talk with other signaling pathways, cancer stem cells etc. This review is focused on the role of non-canonical estrogen receptor signaling in endocrine resistance. Most of the therapeutics which are used currently are targeting the major receptor of estrogen namely ER- $\alpha$. Last two decades has witnessed the discovery of alternate forms of ER- $\alpha$, as well as other receptors for estrogen such as ERRgamma, GPER-1 as well as ER- $\beta$, which are activated not only by estrogen, but also by the therapeutic agents

OPEN ACCESS

Edited by:

Antimo Migliaccio,

University of Campania Luigi

Vanvitelli, Italy

Reviewed by:

Yun Zhu,

University of Texas MD Anderson Cancer Center, United States Domenico lacopetta,

University of Calabria, Italy

*Correspondence: Prathibha Ranganathan pranganathan@chg.res.in

Specialty section: This article was submitted to

Cancer Endocrinology, a section of the journal Frontiers in Endocrinology

Received: 02 August 2019 Accepted: 02 October 2019 Published: 16 October 2019

Citation:

Ranganathan P, Nadig N and Nambiar S (2019) Non-canonical Estrogen Signaling in Endocrine Resistance. Front. Endocrinol. 10:708. doi: 10.3389/fendo.2019.00708 such as tamoxifen that are routinely used in treatment of breast cancer. However, when the alternate receptors are activated, they result in activation of membrane signaling which subsequently activates pathways such as MAPK and GPCR leading to cell-proliferation. This renders the anticipated anti-estrogenic effects of tamoxifen less effective or ineffective. Future research in this area has to focus on the alternate mechanisms and develop a combinatorial strategy, which can complement the existing therapeutics to get better outcome of endocrine therapies.

Keywords: estrogen receptor, tamoxifen, membrane signaling, endocrine resistance, non-genomic actions, selective agonists

\section{INTRODUCTION}

Breast cancer is an extremely heterogenous malignancy and a leading cause of cancer related deaths throughout the world. A large percentage of the breast cancers are estrogen sensitive and respond well to endocrine therapy. This mode of therapy essentially blocks the major proliferative pathway namely Estrogen Receptor (ER) signaling. The major strategies for doing this are

1. Using Selective Estrogen Receptor Modulators (SERMS, Ex: Tamoxifen) to block the binding of estrogen to ER

2. Down regulating the receptor using Selective Estrogen Receptor Down-regulators (SERD, Ex: Fulvestrant)

3. Reducing the synthesis of estrogen using aromatase inhibitors.

For a long time, use of SERMs had been very popular. Despite showing very good effects on ER positive tumors, a large percentage of tumors developed resistance to this mode of treatment. 
Clinicians and researchers have been trying to understand the basis of this resistance to improvise on the treatment strategies. Many mechanisms have been proposed for the development of endocrine resistance. This includes mutations in the ER- $\alpha$, cross talk with other growth factor pathways etc. (1). This article tries to summarize some of the mechanisms, namely the role of alternative forms of ER- $\alpha$, ER- $\beta$, and other receptors for estrogen such as GPER-1 in development of endocrine resistance.

In humans, the endogenous estrogens are estrone (E1), estradiol (E2), and estriol (E3). Among these, estradiol (E2) is the most prevalent and potent. The main actions of estrogens are mediated by the estrogen receptor (ER) which belongs to the family of nuclear hormone receptors. In the classical model for steroid hormone signaling, the hormone enters the cells through the plasma membrane and binds to the compatible receptor which is mostly localized in the cytoplasm. This binding often leads to dimerization followed by nuclear localization. Once in the nucleus, they bind directly to the DNA response elements such as ERE and regulate transcription of target genes, which in turn alters the biological response of the cells. In an alternate mechanism, the receptors do not bind directly to DNA, but still regulate transcription by forming a complex with co-activators or co-repressors [reviewed in $(2,3)]$.

Estrogen receptors, like other nuclear hormone receptors have a modular structure. The $\mathrm{A}$ and the $\mathrm{B}$ domains aid in binding to transcriptional regulators. The $\mathrm{C}$ domain aids in DNA binding and $\mathrm{D}$ forms the hinge region and also harbors the Nuclear Localization Signal, which helps in recognition and binding of specific DNA elements. E domain or the ligand binding domain confers ligand specificity (Figure 1A). In addition the $\mathrm{E}$ and $\mathrm{F}$ domains bind to additional co-regulators via the LXXLL motifs [reviewed in $(2,3)]$.

Classical estrogen signaling is mediated by two major receptors ER- $\alpha$ and ER- $\beta$. These two receptors are encoded by two distinct genes ESR-1 and ESR-2, respectively. The expression of these two genes vary in different tissues. ER- $\alpha$ has a dominant role in tissues such as uterus, mammary glands, pituitary, skeletal muscle, adipose, and bone; whereas, ER- $\beta$ has a major role in ovary, prostate, lung, cardiovascular, and central nervous systems (4). Consistent with this, the knock-out mouse phenotypes of ER- $\alpha$ and ER- $\beta$ are very different. While the ER- $\alpha$ KO are infertile with hypo-trophic uterus, the ER- $\beta$ KO are subfertile and have reduced ovulation (5). There are still many aspects of ER- $\beta$ actions and its role in pathophysiology of estrogen signaling including endocrine resistance that are largely unknown (3).

Estrogen receptors can bind to a variety of pharmacological agents which have either agonist-antagonist or only antagonist properties. These are referred to as SERMs and their effect is dependent on the target tissues. One example of this is tamoxifen which is used as an antagonist in breast cancer, but has agonistic effects on other estrogen target tissues. Raloxifene is antiproliferative in breast but has a protective effect in the bone $(6,7)$. Fulvestrant, is a pure antagonist or Selective Estrogen Receptor Down-regulator (SERD). Both these groups of molecules bind to similar pockets in the ligand binding region of the ER. However, the conformational changes that are responsible for co-activator or co-repressor binding may be different. In the case of the SERMs, the conformations of the ER- $\alpha$-LBD remain flexible and thereby responsible for the antagonist-agonist properties in a context dependent manner. However, in the case of SERD, the binding of ER- $\alpha$ to DNA is also affected (8-10) [reviewed in (3)].

\section{ALTERNATIVE FORMS OF ESTROGEN RECEPTORS}

The most commonly found isoform of ER- $\alpha$ is a $66 \mathrm{kDa}$ protein and is referred to as ER- $\alpha-66$. Besides this, there are other forms of the receptor such as ER- $\alpha-36$ and ER- $\alpha-46$ (Figure 1B), which are located in the cytoplasm and plasma membrane in some tissues and breast cancer cell lines $(11,12)$. These proteins are products of alternative transcripts of the ESR-1 gene (13). There is no strong evidence to suggest the role of these truncated forms in any disease conditions. However, in the absence of full length receptor, these truncated receptors can mediate the rapid non-genomic actions by activating the EGFR/Src/ERK1/2 pathways (14).

Besides the alternative forms, the full length receptor also localizes to the plasma membrane and is responsible for the rapid actions of estrogen (15). The altered localization is due to differential post-translational modifications of ER- $\alpha$ and $\beta$ (16). Mutation at Cys 447 disrupted the palmitoylation and also the ERK activation by estrogen further supporting the role of this modification in the non-genomic actions of estrogen (17). Palmitoylation on the ligand binding domains with the aid of HSP27, leads to interaction with caveolin 1 and transport to lipid rafts and cell membrane. The palmitoylated receptors dimerize within seconds of exposure to estrogen, and activate G- $\alpha$ and $\mathrm{G} \beta \gamma$ in a cell-type dependent manner (18). De-palmitoylation of the receptor leads to re-distribution of the protein and hence modulates the genomic and non-genomic actions also (19).

There are many mutations of the ESR1 gene reported in treatment refractory breast cancers. Amplification of ESR1 as well as gene fusions (ESR1/YAP, ESR1-CCDC170) are likely to be implicated in resistance, but the frequency of occurrence is fairly low $(20,21)$. On the other hand mutations clustered in the LBD have been reported in many endocrine resistant breast cancers (20-26). Advanced detection techniques such as droplet digital PCR and ctDNA analyses also have revealed that these mutations are seen mostly in advanced disease which have been exposed to endocrine therapies [reviewed in (27)]. Preclinical and clinical studies also suggest that these mutations probably exist in a small population of the tumor cells, which get selected under pressure of endocrine therapies and eventually the tumor emerges as endocrine resistant (28, 29).

The ESR1 mutations, which are mostly clustered in the LBD result in ER protein taking a conformation which is activated independent of ligand binding. These mutations were first described in the 1990s using structure-function studies in the absence of estrogen or the presence of antagonists. Y537 is a very commonly mutated site. This mutation makes the 


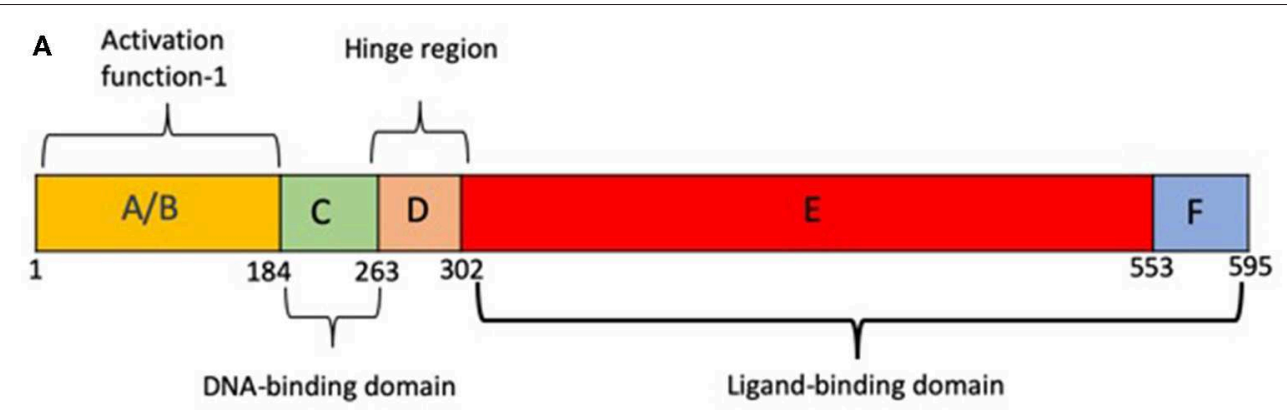

\section{ER $\alpha$}

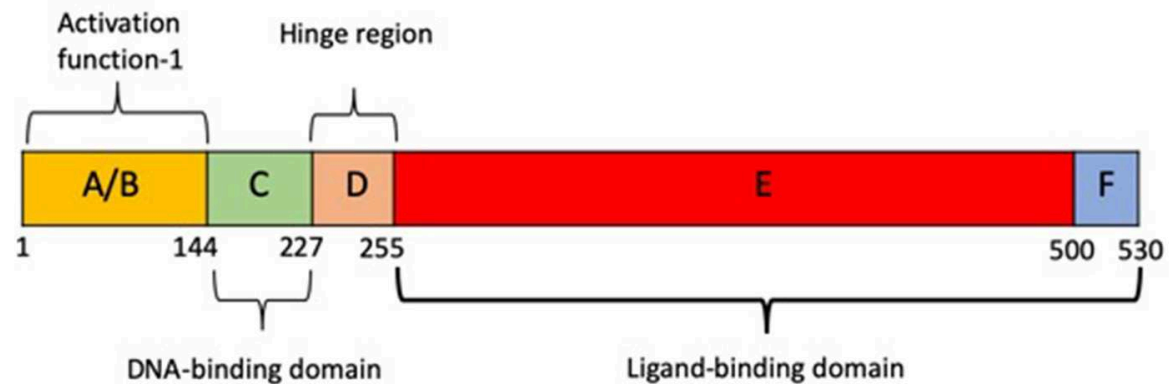

ER $\boldsymbol{\beta}$

B

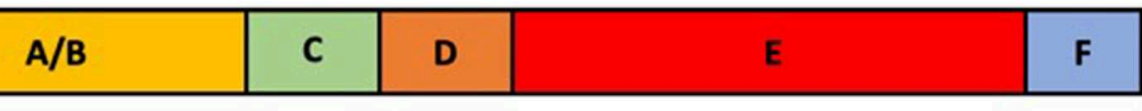

ER- $\alpha-66$

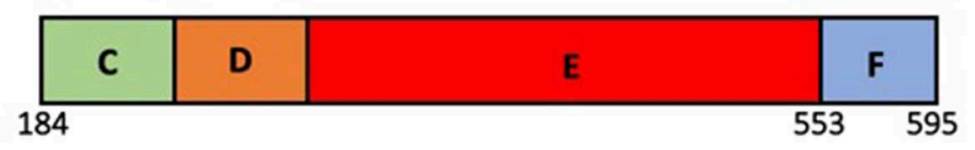

ER- $\alpha-46$

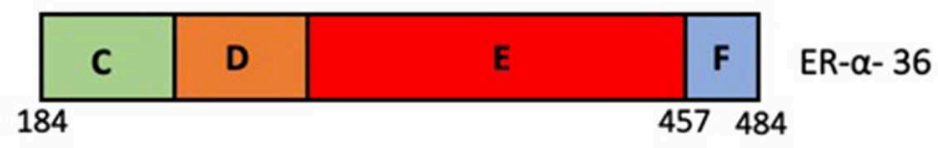

FIGURE 1 | (A) Schematic representation of the domain structure of ER- $\alpha$ and ER- $\beta$. (B) Schematic representation of alternate variants of ER- $\alpha$-products of alternate promoters.

receptor constitutively active and results in reduced efficacy of anti-estrogens. L536, E380, and S463 are some of the other residues mutated in the ER. These mutations result the ER assuming an agonist conformation or reduce their affinities for co-repressors which result in constitutive activity. This subsequently results in insensitivity to endocrine therapies (3032). K303 and S305 mutations have been found to affect sensitivity to endocrine therapies as well as cross-talk with other proliferative pathways such as IGF and Akt (33). A comprehensive review of these and other less frequent mutations and their structure-function implications is very thoroughly described in (34).

The mechanistic insight into the effects of these mutations on the function of the receptor and binding of ligands and antagonists has made it possible to strategize better drug designs and combinations. Increasing dosages, modifying side chains of the drugs for better affinity and potency are being tried. Besides, using ER degrading agents along with antagonists may also be a good strategy to combat endocrine resistance [reviewed in (34)]. 
Besides the variants of ER- $\alpha$, there are other receptors such as the ERR gamma (estrogen-related receptor gamma), which play a role in resistance to tamoxifen. Studies on invasive lobular carcinomas (ILC) of the breast have shown that these resistant tumors have elevated levels of ERR gamma, and also increased AP-1 activation. This alternative signaling overcomes the growth inhibitory effects of tamoxifen rendering these tumors endocrine resistant $(35,36)$. Further, tamoxifen induces cell growth and this can be reverted by simultaneously inhibiting the FGF pathway. This study also suggests that ER drives a unique transcriptional program in these cells (37). This unique transcriptional response may be attributed to ERR gamma. ERR gamma was originally identified as an orphan receptor (38), which is constitutively active and can bind and regulate transcription from DNA elements such as steroidogenic factor 1 response element (SF-1RE) and estrogen response element (39). However, the affinity to these elements is variable. The transcriptional response of ERR gamma is quite different from the other members of this family such as ERR alpha and beta. While ERR alpha and beta constitutively activate transcription from ERE, TRE-Pal, and SF1-RE, it has been demonstrated that the activity of ERR gamma is dependent on the DNA element it binds to, which determines whether it associates with a co-activator such as PGC-1 (peroxisome proliferator-activated receptor gamma coactivator 1) or a co-repressor such as RIP140 (receptor interacting protein 140) $(40,41)$. These two regulators show a similar tissue distribution as $\operatorname{ERR}$ gamma $(38,42)$ and hence their relative levels may also affect ERR gamma activity. It is therefore suggested that these may be responsible for the unique gene expression pattern driven by ERR gamma (43).

\section{ESTROGEN RECEPTOR $\beta$}

The major actions of estrogen are mediated by two estrogen receptors ER- $\alpha$ and ER- $\beta$. The two proteins are coded for by separate genes located on chromosomes 6 and 14, respectively. Although ER- $\alpha$ and ER- $\beta$ share a lot structural similarities (44) in terms of their domain organization (Figure 1A), there are differences in the ligand binding domain which makes the affinities for ligands different. Estrogen can activate both the receptors, but due to the spatio-temporal differences in the expression of the receptors, the biological effects may be different. There are sub-type selective agonists such as diarylpropionitrile which have been used in understanding these differences (45). The two receptors can form hetero-dimers which can bind DNA. The functionality of heterodimers in the presence of homodimers is not clear $(46,47)$. In many cases, ER- $\beta$ antagonizes the effects of ER- $\alpha$ signaling. The knock-out phenotypes of the two receptors also suggest that the role of these two proteins may overlap to some extent but are more unique than similar (47). However, the exact mode of action of ER- $\beta$ and its relevance in disease is less well-understood.

In the breast tissue, the number of cell-types expressing ER- $\beta$ is more than ER- $\alpha$ (48). While ER- $\alpha$ is mostly localized to the epithelial cells, ER- $\beta$ is also seen in the stroma (49). Studies on mouse models have revealed that while ER- $\alpha$ is responsible for proliferative effect of estrogen, ER- $\beta$ is responsible for repressing proliferation and inducing apoptosis [reviewed in (50)]. Supporting this, there are many studies which have shown a correlation between increased ER- $\beta$ levels with better disease free survival (51). Interestingly, in TNBC, which lacks ER- $\alpha$, there is a subset of tumors that express ER- $\beta$. In these tumors, activating this pathway either with estrogen or a selective agonist inhibits cell proliferation by affecting the expression of several cell cycle related proteins thereby conferring a tumor suppressive role to ER$\beta$ (52).

ER- $\beta$ levels vary in IDC and ILC. In a clinical trial it was observed that ILC shows better response to aromatase inhibitor treatment as compared to tamoxifen. This could be because, in the presence of ER- $\beta$, tamoxifen activates AP- 1 site, and stimulates proliferation (53). Although other studies have shown a tumor suppressor action of ER- $\beta$, this study seems to indicate that the action depends on the context and the presence of certain co-factors including the presence of truncated ER- $\alpha$.

Besides the expression of ER- $\beta$ in tumor cells, there is evidence that several cells of the tumor microenvironment express the ERs to different extents. Among these, the immune cells are known to be affected by estrogen effects significantly (54). Studies have shown that a large percentage of TILs (tumor infiltrating leukocytes) express ER- $\beta$ but not ER- $\alpha$. Tamoxifen can act as an agonist for ER- $\beta$ by activating AP-1, Sp1, and NF- $\kappa$ B sites. Therefore, tamoxifen treatment could have a significant impact on the immune surveillance. However, the exact modes of action and also the role of these leukocytes in tumor progression are yet to be characterized.

Considering the tumor suppressive roles of ER- $\beta$, and also the context dependent effects, it appears that selectively activating ER- $\beta$ may be a good treatment strategy in breast cancer including overcoming resistance to tamoxifen. Many selective ER- $\beta$ agonists are being tried in clinical trials [reviewed in (44)]. Also there are many natural sources of these agonists such as phyto-estrogens, isoflavones etc., which may hold promise in cancer prevention and treatment.

\section{NON-NUCLEAR ESTROGEN RECEPTOR GPER-1}

GPER-1 or GPR30 was originally classified as an orphan receptor and later identified as a non-nuclear estrogen receptor (55). In the subsequent years, it was demonstrated that GPER-1 was indeed a receptor estrogen and its natural ligand was $17-\beta$ estradiol (56). In fact, some studies have shown the effect of estrogen on cells which lack ER- $\alpha$, suggested that some of the effects of estrogen which were originally believed to be mediated by ER- $\alpha$, may in fact be mediated by GPER-1 (57).

GPER-1 is a G protein coupled receptor. It has an $\mathrm{N}$ terminal extracellular domain and a C-terminal intracellular domain. Upon binding to 17- $\beta$-estradiol, it elicits a rapid and transient activation of many signaling pathways. There is an increase in cAMP production, intracellular calcium, synthesis of phosphotidyl inositol 3,4,5-triphosphate, transactivation of 
EGFR followed by activation of pathways such as PI3K-Akt and MAPK [reviewed in (58)]. Numerous functions have been attributed to GPR30 in a variety of cell types, which is supported by the knock out mouse phenotypes [reviewed in (59)].

The role GPER-1 in cancer is still unclear. In ER negative breast cancer cells, activating GPER-1 by an agonist such as G1, led to cell cycle arrest and apoptosis suggesting GPER-1 as a promising target for breast cancer therapy (59, 60). G-1 has also shown inhibition of proliferation in ER- $\alpha$ positive celllines (61). On the contrary, some studies show that in TNBC, GPER-1 is frequently over expressed and the growth of these tumors is driven by estrogen. Therefore, selectively blocking GPER-1 may be a good therapeutic approach (62). Mouse models show that mice lacking GPER-1 form smaller and histologically lower grade tumors compared to wild type mice (63). GPER-1 expression has been shown to be an indicator of poor prognosis in ovarian and endometrial cancers (64). It is also demonstrated that $17-\beta$-estradiol can bind and activate this receptor and the genes that are activated are those involved in cell proliferation, migration etc. Blocking the GPR30 action using inhibitors such as calicosyn can inhibit proliferation in breast cancer cells (65). This is seen not only in cancer cells but also in the associated stromal cells (66). Tamoxifen and 4-hydroxy tamoxifen, which are the commonly used agents in endocrine therapy, can activate GPER1. Once activated, this receptor further signals by activation of the $G$ proteins, resulting in increased levels of cAMP and a series of events which leads to trans-activation of EGFR and activation of the ERK and MAPK pathways (67). Other agents used in endocrine therapy such as fulvestrant and raloxifene, which antagonize ER- $\alpha$ actions also act as agonists of GPER-1 and can promote tumor progression (68).

In the tumor microenvironment, GPER-1 activation also activates HIF-1- $\alpha$ dependent pathways aiding in angiogenesis and progression of breast cancer (69).

There are many studies which demonstrate the protumorigenic effects of GPER-1 activation by tamoxifen, in a ER- $\alpha$ independent manner, which supports a role for GPER1 in the development of resistance to endocrine therapies, particularly with SERMS [reviewed in (59)]. A study by
$\mathrm{Yu}$ et al., has demonstrated that activation of GPER-1 and cytoplasmic localization in the stromal fibroblasts, activates the GPER/cAMP/PKA/CREB axis, which in turn triggers a metabolic switch in the CAFs. This switch provides the extra pyruvate and lactate to the tumor cells. This reprogrammed metabolism confers the tumor cells resistance to multiple therapeutics including tamoxifen, herceptin and chemotherapy (70). Targeting the GPER-1 or preventing the cytoplasmic localization may be a useful approach to retain drug sensitivity. Studies using selective agonists and antagonists for estrogen receptors, has made it more evident that GPER-1 has a major role to play in resistance to chemotherapy in ER positive breast cancers and also other cancers such as ovary and endometrium. Considering that the effects of GPER-1 is seen both in the tumors and in the microenvironment, targeting GPER-1 seems to be an attractive therapeutic strategy.

\section{ANDROGEN RECEPTOR}

The androgen receptor has been seen to be expressed in a large percentage of breast tumors (71-75) including hereditary forms of breast cancer (76). Studies have shown that ER negative cancers do respond to AR blockade therapy suggesting a role for $\mathrm{AR}$ in prognosis $(77,78)$. It has also been demonstrated that tamoxifen resistant breast cancers show elevated expression of $\mathrm{AR}$ and this resistance can be reversed by AR antagonists such as bicalutamide (79). AR has also been implicated in resistance to aromatase inhibitors (80). Several studies have confirmed the role of AR in endocrine resistant breast cancers [(81) and reviewed in $(82,83)]$ making AR an important consideration in treatment of breast cancer.

Regardless of how it is initiated, the estrogen signaling from membrane can result in cell proliferation, altered metabolism, altered immune response as well as angiogenesis, all of which help in cancer cell survival, thereby promoting resistance. Considering the above discussed aspects of estrogen signaling and resistance to endocrine therapies, the following concerns emerge. Since estrogen is a major proliferative signaling pathway in cancers such as breast cancer, this has been the major target

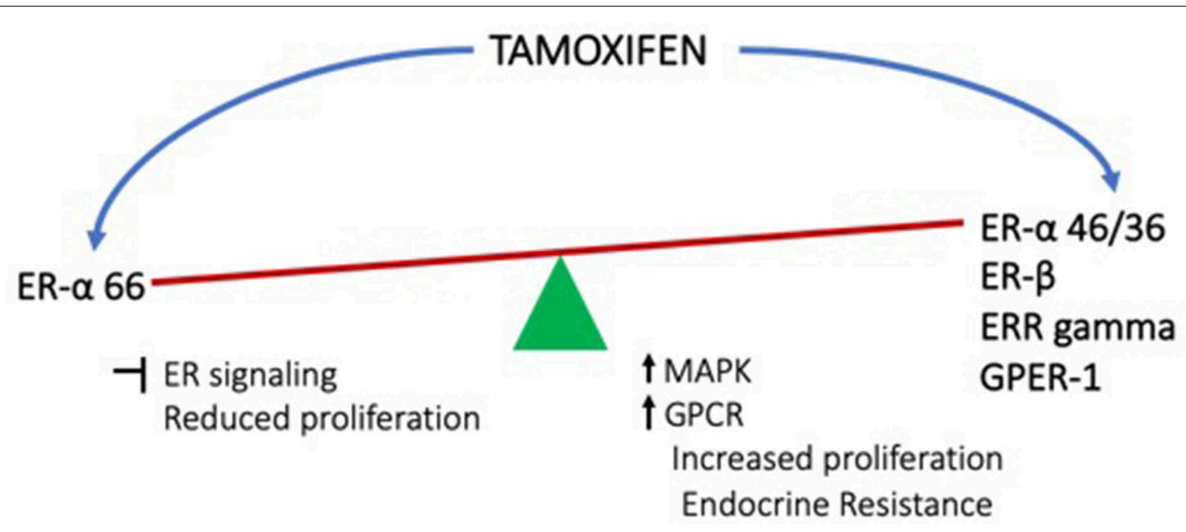

FIGURE 2 | Effects of tamoxifen (endocrine therapy) on the conventional estrogen signaling from ER- $\alpha$ and the non-canonical signaling from other receptors. 
for therapy. Prior to discovery of other receptors, it was believed that the majority of actions of estrogen are mediated by ER- $\alpha$ and drugs targeting this receptor had been a choice strategy for therapy. Resistance to endocrine therapy was seen quite frequently, which was one of the major challenges. However, with the discovery of alternative forms of ER- $\alpha$ as well as other receptors for estrogen, non-canonical signaling has been gaining attention as one of the major causes of resistance. Since, the alternative receptors can be activated not only by estrogen, but also by some of the antagonists including tamoxifen, it becomes very important to understand the working of these receptors more comprehensively (Figure 2). This understanding may help in development of better therapeutic strategies. When and what determines the differential promotor usage for the variant isoforms of ER- $\alpha$ ? How is the timing and extent of palmitoylation of the receptor controlled? How does the ER- $\alpha$ to ER- $\beta$ ratio influence the treatment outcome and how can this be regulated? How does presence of GPER-1 influence the behavior of the tumor and its microenvironment in response to therapy? And what is the status of $\mathrm{AR}$ in the tumors? Combinatorial therapy definitely seems to hold better

\section{REFERENCES}

1. Nardone A, De Angelis C, Trivedi MV, Osborne CK, Schiff R. The changing role of ER in endocrine resistance. Breast. (2015) 24 (Suppl 2):S60-6. doi: 10.1016/j.breast.2015.07.015

2. Levin ER, Hammes SR. Nuclear receptors outside the nucleus: extranuclear signalling by steroid receptors. Nat Rev Mol Cell Biol. (2016) 17:783-97. doi: 10.1038/nrm.2016.122

3. Yaşar P, Ayaz G, User SD, Güpür G, Muyan M. Molecular mechanism of estrogen-estrogen receptor signaling. Reprod Med Biol. (2017) 16:4-20. doi: 10.1002/rmb2.12006

4. Harris HA. Estrogen receptor-beta: recent lessons from in vivo studies. Mol Endocrinol. (2007) 21:1-13. doi: 10.1210/me.2005-0459

5. Hamilton KJ, Arao Y, Korach KS. Estrogen hormone physiology: reproductive findings from estrogen receptor mutant mice. Reprod Biol. (2014) 14:38. doi: 10.1016/j.repbio.2013.12.002

6. Jordan VC, O'Malley BW. Selective estrogen-receptor modulators and antihormonal resistance in breast cancer. J Clin Oncol. (2007) 25:5815-24. doi: 10.1200/JCO.2007.11.3886

7. Kousteni S, Chen JR, Bellido T, Han L, Ali AA, O'Brien CA, et al. Reversal of bone loss in mice by nongenotropic signaling of sex steroids. Science. (2002) 298:843-6. doi: 10.1126/science.1074935

8. McDonnell DP, Wardell SE. The molecular mechanisms underlying the pharmacological actions of ER modulators: implications for new drug discovery in breast cancer. Curr Opin Pharmacol. (2010) 10:620-8. doi: 10.1016/j.coph.2010.09.007

9. Muyan M, Callahan LM, Huang Y, Lee AJ. The ligand-mediated nuclear mobility and interaction with estrogen-responsive elements of estrogen receptors are subtype specific. J Mol Endocrinol. (2012) 49:249-66. doi: 10.1530/JME-12-0097

10. Yi P, Driscoll MD, Huang J, Bhagat S, Hilf R, Bambara RA, et al. The effects of estrogen-responsive element- and ligand-induced structural changes on the recruitment of cofactors and transcriptional responses by ER alpha and ER beta. Mol Endocrinol. (2002) 16:674-93. doi: 10.1210/me.16.4.674

11. Li L, Haynes MP, Bender JR. Plasma membrane localization and function of the estrogen receptor alpha variant (ER46) in human endothelial cells. Proc Natl Acad Sci USA. (2003) 100:4807-12. doi: 10.1073/pnas.0831079100

12. Wang Z, Zhang X, Shen P, Loggie BW, Chang Y, Deuel TF. A variant of estrogen receptor-\{alpha\}, hER-\{alpha\}36: transduction of estrogen- and promise, but developing the right combinations is the herculean task. Future research needs to be focused on understanding the balance between the various modes of estrogen signaling and how this could be utilized optimally for better therapeutic outcome.

\section{AUTHOR CONTRIBUTIONS}

PR collected relevant literature and wrote the manuscript. NN and SN assisted in illustrations, formatting, and collection of literature.

\section{ACKNOWLEDGMENTS}

We sincerely thank Dr. Anil Mukund Limaye (IIT-Guwahati, India) and Dr. Anjali Anoop Karande (Centre for Human Genetics, Bengaluru, India) for critical reading of the manuscript. Financial assistance from Department of Biotechnology, Government of India (BT/PR16071/NER/95/63/2015; Appl No: BMB/2015/14 dated 13th February 2017) and Centre for Human Genetics, Bengaluru, India is duly acknowledged.

antiestrogen-dependent membrane-initiated mitogenic signaling. Proc Natl Acad Sci USA. (2006) 103:9063-8. doi: 10.1073/pnas.0603339103

13. Flouriot G, Griffin C, Kenealy M, Sonntag-Buck V, Gannon F. Differentially expressed messenger RNA isoforms of the human estrogen receptoralpha gene are generated by alternative splicing and promoter usage. $\mathrm{Mol}$ Endocrinol. (1998) 12:1939-54. doi: 10.1210/mend.12.12.0209

14. Zhang XT, Kang LG, Ding L, Vranic S, Gatalica Z, Wang ZY. A positive feedback loop of ER- $\alpha 36 /$ EGFR promotes malignant growth of ER-negative breast cancer cells. Oncogene. (2011) 30:770-80. doi: 10.1038/onc.2010.458

15. Hammes SR, Levin ER. Extranuclear steroid receptors: nature and actions. Endocr Rev. (2007) 28:726-41. doi: 10.1210/er.2007-0022

16. Marino M, Ascenzi P, Acconcia F. S-palmitoylation modulates estrogen receptor alpha localization and functions. Steroids. (2006) 71:298-303. doi: 10.1016/j.steroids.2005.09.011

17. Acconcia F, Ascenzi P, Fabozzi G, Visca P, Marino M. S-palmitoylation modulates human estrogen receptor-alpha functions. Biochem Biophys Res Commun. (2004) 316:878-83. doi: 10.1016/j.bbrc.2004.02.129

18. Kumar P, Wu Q, Chambliss KL, Yuhanna IS, Mumby SM, Mineo C, et al. Direct interactions with $\mathrm{G} \alpha \mathrm{i}$ and $\mathrm{G} \beta \gamma$ mediate nongenomic signaling by estrogen receptor $\alpha$. Mol Endocrinol. (2007) 21:137080. doi: 10.1210/me.2006-0360

19. Galluzzo P, Ascenzi P, Bulzomi P, Marino M. The nutritional flavanone naringenin triggers antiestrogenic effects by regulating estrogen receptor alpha-palmitoylation. Endocrinology. (2008) 149:2567-75. doi: 10.1210/en.2007-1173

20. Li S, Shen D, Shao J, Crowder R, Liu W, Prat A, et al. Endocrine-therapy-resistant ESR1 variants revealed by genomic characterization of breast-cancer-derived xenografts. Cell Rep. (2013) 4:1116-30. doi: 10.1016/j.celrep.2013.08.022

21. Veeraraghavan J, Tan Y, Cao XX, Kim JA, Wang X, Chamness GC, et al. Recurrent ESR1-CCDC170 rearrangements in an aggressive subset of oestrogen receptor-positive breast cancers. Nat Commun. (2014) 5:4577. doi: $10.1038 /$ ncomms5577

22. Toy W, Shen Y, Won H, Green B, Sakr RA, Will M, et al. ESR1 ligandbinding domain mutations in hormone-resistant breast cancer. Nat Genet. (2013) 45:1439-45. doi: 10.1038/ng.2822

23. Robinson DR, Wu YM, Vats P, Su F, Lonigro RJ, Cao X, et al. Activating ESR1 mutations in hormone-resistant metastatic breast cancer. Nat Genet. (2013) 45:1446-51. doi: 10.1038/ng.2823 
24. Merenbakh-Lamin K, Ben-Baruch N, Yeheskel A, Dvir A, Soussan-Gutman $\mathrm{L}$, Jeselsohn R, et al. D538G mutation in estrogen receptor- $\alpha$ : a novel mechanism for acquired endocrine resistance in breast cancer. Cancer Res. (2013) 73:6856-64. doi: 10.1158/0008-5472.CAN-13-1197

25. Jeselsohn R, Yelensky R, Buchwalter G, Frampton G, Meric-Bernstam F, Gonzalez-Angulo AM, et al. Emergence of constitutively active estrogen receptor- $\alpha$ mutations in pretreated advanced estrogen receptor-positive breast cancer. Clin Cancer Res. (2014) 20:1757-67. doi: 10.1158/1078-0432.CCR-13-2332

26. Fumagalli D, Wilson TR, Salgado R, Lu X, Yu J, O’Brien C, et al. Somatic mutation, copy number and transcriptomic profiles of primary and matched metastatic estrogen receptor-positive breast cancers. Ann Oncol. (2016) 27:1860-6. doi: 10.1093/annonc/mdw286

27. Jeselsohn R, De Angelis C, Brown M, Schiff R. The evolving role of the estrogen receptor mutations in endocrine therapy-resistant breast cancer. Curr Oncol Rep. (2017) 19:35. doi: 10.1007/s11912-017-0591-8

28. Greaves M, Maley CC. Clonal evolution in cancer. Nature. (2012) 481:30613. doi: 10.1038/nature 10762

29. Turner NC, Reis-Filho JS. Genetic heterogeneity and cancer drug resistance. Lancet Oncol. (2012) 13:e178-85. doi: 10.1016/S1470-2045(11)70335-7

30. Fribbens C, O'Leary B, Kilburn L, Hrebien S, Garcia-Murillas I, Beaney $M$, et al. Plasma ESR1 mutations and the treatment of estrogen receptor-positive advanced breast cancer. J Clin Oncol. (2016) 34:2961-8. doi: 10.1200/JCO.2016.67.3061

31. Chandarlapaty S, Chen D, He W, Sung P, Samoila A, You D, et al. Prevalence of ESR1 mutations in cell-free DNA and outcomes in metastatic breast cancer: a secondary analysis of the BOLERO-2 clinical trial. JAMA Oncol. (2016) 2:1310-5. doi: 10.1001/jamaoncol.2016.1279

32. Toy W, Weir H, Razavi P, Lawson M, Goeppert AU, Mazzola A, et al. Activating ESR1 mutations differentially affect the efficacy of ER antagonists. Cancer Discov. (2017) 7:277-87. doi: 10.1158/2159-8290

33. Barone I, Iacopetta D, Covington KR, Cui Y, Tsimelzon A, Beyer A, et al. Phosphorylation of the mutant K303R estrogen receptor alpha at serine 305 affects aromatase inhibitor sensitivity. Oncogene. (2010) 29:240414. doi: $10.1038 /$ onc. 2009.520

34. Katzenellenbogen JA, Mayne CG, Katzenellenbogen BS, Greene GL, Chandarlapaty S. Structural underpinnings of oestrogen receptor mutations in endocrine therapy resistance. Nat Rev Cancer. (2018) 18:377-88. doi: 10.1038/s41568-018-0001-Z

35. Riggins RB, Lan JP, Zhu Y, Klimach U, Zwart A, Cavalli LR, et al. ERRgamma mediates tamoxifen resistance in novel models of invasive lobular breast cancer. Cancer Res. (2008) 68:8908-17. doi: 10.1158/0008-5472.CAN-08-2669

36. Stires H, Heckler MM, Fu X, Li Z, Grasso CS, Quist MJ, et al. Integrated molecular analysis of Tamoxifen-resistant invasive lobular breast cancer cells identifies MAPK and GRM/mGluR signaling as therapeutic vulnerabilities. Mol Cell Endocrinol. (2018) 471:105-17. doi: 10.1016/j.mce.2017.09.024

37. Sikora MJ, Cooper KL, Bahreini A, Luthra S, Wang G, Chandran UR, et al. Invasive lobular carcinoma cell lines are characterized by unique estrogenmediated gene expression patterns and altered tamoxifen response. Cancer Res. (2014) 74:1463-74. doi: 10.1158/0008-5472.CAN-13-2779

38. Hong H, Yang L, Stallcup MR. Hormone-independent transcriptional activation and coactivator binding by novel orphan nuclear receptor ERR3. J Biol Chem. (1999) 274:22618-26. doi: 10.1074/jbc.274.32.22618

39. Heard DJ, Norby PL, Holloway J, Vissing H. Human ERRgamma, a third member of the estrogen receptor-related receptor (ERR) subfamily of orphan nuclear receptors: tissue-specific isoforms are expressed during development and in the adult. Mol Endocrinol. (2000) 14:382-92. doi: 10.1210/mend.14.3.0431

40. Knutti D, Kaul A, Kralli A. A tissue-specific coactivator of steroid receptors, identified in a functional genetic screen. Mol Cell Biol. (2000) 20:241122. doi: 10.1128/MCB.20.7.2411-2422.2000

41. Lee $\mathrm{CH}$, Chinpaisal C, Wei LN. Cloning and characterization of mouse RIP140, a corepressor for nuclear orphan receptor TR2. Mol Cell Biol. (1998) 18:6745-55. doi: 10.1128/MCB.18.11.6745

42. Sanyal S, Kim JY, Kim HJ, Takeda J, Lee YK, Moore DD, et al. Differential regulation of the orphan nuclear receptor small heterodimer partner (SHP) gene promoter by orphan nuclear receptor ERR isoforms. J Biol Chem. (2002) 277:1739-48. doi: 10.1074/jbc.M106140200
43. Sanyal S, Matthews J, Bouton D, Kim HJ, Choi HS, Treuter E, et al. Deoxyribonucleic acid response element-dependent regulation of transcription by orphan nuclear receptor estrogen receptor-related receptor gamma. Mol Endocrinol. (2004) 18:312-25. doi: 10.1210/me.2003-0165

44. Ramasamy K, Samayoa C, Krishnegowda N, Tekmal RR. Therapeutic use of estrogen receptor $\beta$ agonists in prevention and treatment of endocrine therapy resistant breast cancers: observations from preclinical models. Prog Mol Biol Transl Sci. (2017) 151:177-94. doi: 10.1016/bs.pmbts.2017.08.002

45. Meyers MJ, Sun J, Carlson KE, Marriner GA, Katzenellenbogen BS, Katzenellenbogen JA. Estrogen receptor-beta potency-selective ligands: structure-activity relationship studies of diarylpropionitriles and their acetylene and polar analogues. J Med Chem. (2001) 44:4230-51. doi: 10.1021/jm010254a

46. Cowley SM, Hoare S, Mosselman S, Parker MG. Estrogen receptors alpha and beta form heterodimers on DNA. J Biol Chem. (1997) 272:1985862. doi: $10.1074 /$ jbc.272.32.19858

47. Matthews J, Gustafsson JA. Estrogen signaling: a subtle balance between ER alpha and ER beta. Mol Interv. (2003) 3:281-92. doi: 10.1124/mi.3.5.281

48. Huang B, Omoto $\mathrm{Y}$, Iwase $\mathrm{H}$, Yamashita H, Toyama T, Coombes RC, et al. Differential expression of estrogen receptor $\alpha, \beta 1$, and $\beta 2$ in lobular and ductal breast cancer. Proc Natl Acad Sci USA. (2014) 111:19338. doi: 10.1073/pnas.1323719111

49. Li S, Han B, Liu G, Li S, Ouellet J, Labrie F, et al. Immunocytochemical localization of sex steroid hormone receptors in normal human mammary gland. J Histochem Cytochem. (2010) 58:509-15. doi: 10.1369/jhc.2009.954644

50. Thomas C, Gustafsson J. The different roles of ER subtypes in cancer biology and therapy. Nat Rev Cancer. (2011) 11:597-608. doi: 10.1038/nrc3093

51. Myers E, Fleming FJ, Crotty TB, Kelly G, McDermott EW, O'higgins NJ, et al. Inverse relationship between ER-beta and SRC-1 predicts outcome in endocrine-resistant breast cancer. Br J Cancer. (2004) 91:168793. doi: $10.1038 /$ sj.bjc. 6602156

52. Reese JM, Bruinsma ES, Monroe DG, Negron V, Suman VJ, Ingle JN, et al. ER $\beta$ inhibits cyclin dependent kinases 1 and 7 in triple negative breast cancer. Oncotarget. (2017) 8:96506-21. doi: 10.18632/oncotarget.21787

53. Kushner PJ, Agard DA, Greene GL, Scanlan TS, Shiau AK, Uht RM, et al. Estrogen receptor pathways to AP-1. J Steroid Biochem Mol Biol. (2000) 74:311-7. doi: 10.1016/S0960-0760(00)00108-4

54. Cunningham M, Gilkeson G. Estrogen receptors in immunity and autoimmunity. Clin Rev Allergy Immunol. (2011) 40:6673. doi: $10.1007 / \mathrm{s} 12016-010-8203-5$

55. Filardo EJ, Quinn JA, Bland KI, Frackelton AR. Estrogen-induced activation of Erk-1 and Erk-2 requires the G protein-coupled receptor homolog, GPR30, and occurs via trans-activation of the epidermal growth factor receptor through release of HB-EGF. Mol Endocrinol. (2000) 14:164960. doi: $10.1210 /$ mend.14.10.0532

56. Revankar CM, Cimino DF, Sklar LA, Arterburn JB, Prossnitz ER. A transmembrane intracellular estrogen receptor mediates rapid cell signaling. Science. (2005) 307:1625-30. doi: 10.1126/science.1106943

57. Filardo EJ, Quinn JA, Frackelton AR, Bland KI. Estrogen action via the G protein-coupled receptor, GPR30: stimulation of adenylyl cyclase and cAMPmediated attenuation of the epidermal growth factor receptor-to-MAPK signaling axis. Mol Endocrinol. (2002) 16:70-84. doi: 10.1210/mend.16.1.0758

58. Prossnitz ER, Barton M. The G-protein-coupled estrogen receptor GPER in health and disease. Nat Rev Endocrinol. (2011) 7:715-26. doi: 10.1038/nrendo.2011.122

59. Molina L, Figueroa CD, Bhoola KD, Ehrenfeld P. GPER $1 / G P R 30$ a novel estrogen receptor sited in the cell membrane: therapeutic coupling to breast cancer. Expert Opin Ther

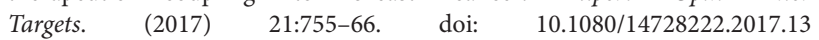
50264

60. Wei W, Chen ZJ, Zhang KS, Yang XL, Wu YM, Chen XH, et al. The activation of $G$ protein-coupled receptor 30 (GPR30) inhibits proliferation of estrogen receptor-negative breast cancer cells in vitro and in vivo. Cell Death Dis. (2014) 5:e1428. doi: 10.1038/cddis.2014.398

61. Ariazi EA, Brailoiu E, Yerrum S, Shupp HA, Slifker MJ, Cunliffe HE, et al. The G protein-coupled receptor GPR30 inhibits proliferation of estrogen receptor-positive breast cancer cells. Cancer Res. (2010) 70:118494. doi: 10.1158/0008-5472.CAN-09-3068 
62. Girgert R, Emons G, Gründker C. 17ß-estradiol-induced growth of triplenegative breast cancer cells is prevented by the reduction of GPER expression after treatment with gefitinib. Oncol Rep. (2017) 37:12128. doi: 10.3892/or.2016.5306

63. Marjon NA, Hu C, Hathaway HJ, Prossnitz ER. G protein-coupled estrogen receptor regulates mammary tumorigenesis and metastasis. Mol Cancer Res. (2014) 12:1644-54. doi: 10.1158/1541-7786.MCR-14-0128-T

64. Smith HO, Arias-Pulido H, Kuo DY, Howard T, Qualls CR, Lee SJ, et al. GPR30 predicts poor survival for ovarian cancer. Gynecol Oncol. (2009) 114:465-71. doi: 10.1016/j.ygyno.2009.05.015

65. Tian J, Wang Y, Zhang X, Ren Q, Li R, Huang Y, et al. Calycosin inhibits the in vitro and in vivo growth of breast cancer cells through WDR7-7-GPR30 Signaling. J Exp Clin Cancer Res. (2017) 36:153. doi: 10.1186/s13046-017-0625-y

66. Pisano A, Santolla MF, De Francesco EM, De Marco P, Rigiracciolo DC, Perri MG, et al. GPER, IGF-IR, and EGFR transduction signaling are involved in stimulatory effects of zinc in breast cancer cells and cancer-associated fibroblasts. Mol Carcinog. (2017) 56:580-93. doi: 10.1002/mc.22518

67. Filardo EJ, Thomas P. GPR30: a seven-transmembrane-spanning estrogen receptor that triggers EGF release. Trends Endocrinol Metab. (2005) 16:3627. doi: 10.1016/j.tem.2005.08.005

68. Jacenik D, Cygankiewicz AI, Krajewska WM. The G protein-coupled estrogen receptor as a modulator of neoplastic transformation. Mol Cell Endocrinol. (2016) 429:10-8. doi: 10.1016/j.mce.2016.04.011

69. Lappano R, Rigiracciolo D, De Marco P, Avino S, Cappello AR, Rosano C, et al. Recent advances on the role of $G$ proteincoupled receptors in hypoxia-mediated signaling. AAPS J. (2016) 18:305-10. doi: 10.1208/s12248-016-9881-6

70. Yu T, Yang G, Hou Y, Tang X, Wu C, Wu XA, et al. Cytoplasmic GPER translocation in cancer-associated fibroblasts mediates cAMP/PKA/CREB/glycolytic axis to confer tumor cells with multidrug resistance. Oncogene. (2017) 36:2131-45. doi: 10.1038/onc.2016.370

71. Moinfar F, Okcu M, Tsybrovskyy O, Regitnig P, Lax SF, Weybora W, et al. Androgen receptors frequently are expressed in breast carcinomas: potential relevance to new therapeutic strategies. Cancer. (2003) 98:703-11. doi: $10.1002 / \mathrm{cncr} .11532$

72. Gonzalez-Angulo AM, Stemke-Hale K, Palla SL, Carey M, Agarwal R, Meric-Berstam F, et al. Androgen receptor levels and association with PIK3CA mutations and prognosis in breast cancer. Clin Cancer Res. (2009) 15:2472-8. doi: 10.1158/1078-0432.CCR-08-1763

73. Birrell SN, Bentel JM, Hickey TE, Ricciardelli C, Weger MA, Horsfall DJ, et al. Androgens induce divergent proliferative responses in human breast cancer cell lines. J Steroid Biochem Mol Biol. (1995) 52:459-67. doi: 10.1016/0960-0760(95)00005-K

74. Buchanan G, Birrell SN, Peters AA, Bianco-Miotto T, Ramsay K, Cops EJ, et al. Decreased androgen receptor levels and receptor function in breastcancer contribute to the failure of response to medroxyprogesterone acetate. Cancer Res. (2005) 65:8487-96. doi: 10.1158/0008-5472.CAN-04-3077

75. Doane AS, Danso M, Lal P, Donaton M, Zhang L, Hudis C, et al. An estrogen receptor-negative breast cancer subset characterized by a hormonally regulated transcriptional program and response to androgen. Oncogene. (2006) 25:3994-4008. doi: 10.1038/sj.onc.1209415

76. Pristauz G, Petru E, Stacher E, Geigl JB, Schwarzbraun T, Tsybrovskyy $\mathrm{O}$, et al. Androgen receptor expression in breast cancer patients tested for BRCA1 and BRCA2 mutations. Histopathology. (2010) 57:877-84. doi: 10.1111/j.1365-2559.2010.03724.x

77. Ni M, Chen Y, Lim E, Wimberly H, Bailey ST, Imai Y, et al. Targeting androgen receptor in estrogen receptor-negative breast cancer. Cancer Cell. (2011) 20:119-31. doi: 10.1016/j.ccr.2011.05.026

78. Lehmann BD, Bauer JA, Chen X, Sanders ME, Chakravarthy AB, Shyr Y, et al. Identification of human triple-negative breast cancer subtypes and preclinical models for selection of targeted therapies. J Clin Invest. (2011) 121:2750-67. doi: 10.1172/JCI45014

79. De Amicis F, Thirugnansampanthan J, Cui Y, Selever J, Beyer A, Parra I, et al. Androgen receptor overexpression induces tamoxifen resistance in human breast cancer cells. Breast Cancer Res Treat. (2010) 121:111. doi: 10.1007/s10549-009-0436-8

80. Rechoum Y, Rovito D, Iacopetta D, Barone I, Andò, S., Weigel, N. L., et al. AR collaborates with ER $\alpha$ in aromatase inhibitor-resistant breast cancer. Breast Cancer Res Treat. (2014) 147:473-85. doi: 10.1007/s10549-014-3082-8

81. D'Amato NC, Gordon MA, Babbs B, Spoelstra NS, Carson Butterfield KT, Torkko KC, et al. Cooperative dynamics of $\mathrm{AR}$ and ER activity in breast cancer. Mol Cancer Res. (2016) 14:1054-67. doi: 10.1158/1541-7786.MCR-16-0167

82. Hanamura T, Hayashi SI. Overcoming aromatase inhibitor resistance in breast cancer: possible mechanisms and clinical applications. Breast Cancer. (2018) 25:379-91. doi: 10.1007/s12282-017-0772-1

83. Iacopetta D, Rechoum Y, Fuqua SA. The role of androgen receptor in breast cancer. Drug Discov Today Dis Mech. (2012) 9:e19-27. doi: 10.1016/j.ddmec.2012.11.003

Conflict of Interest: The authors declare that the research was conducted in the absence of any commercial or financial relationships that could be construed as a potential conflict of interest.

Copyright (C) 2019 Ranganathan, Nadig and Nambiar. This is an open-access article distributed under the terms of the Creative Commons Attribution License (CC BY). The use, distribution or reproduction in other forums is permitted, provided the original author(s) and the copyright owner(s) are credited and that the original publication in this journal is cited, in accordance with accepted academic practice. No use, distribution or reproduction is permitted which does not comply with these terms. 